\title{
Ovarian development and spawning of Serra Spanish mackerel in coastal waters of Northeastern Brazil
}

\author{
Chellappa, S. ${ }^{\text {a* }}$ Lima, JTAX. ${ }^{\mathrm{b}}$, Araújo, A. ${ }^{\mathrm{b}}$ and Chellappa, NT. ${ }^{\mathrm{a}}$ \\ aPrograma de Pós-Graduação em Ecologia, \\ Departamento de Oceanografia e Limnologia, Centro de Biociências, \\ Universidade Federal do Rio Grande do Norte - UFRN, \\ CEP 59072-970, Natal, RN, Brazil

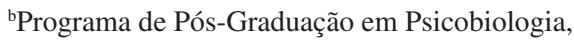 \\ Departamento de Fisiologia, Centro de Biociências, \\ Universidade Federal do Rio Grande do Norte - UFRN, \\ Av. Salgado Filho, 3000, Lagoa Nova, CEP 59072-970, Natal, RN, Brazil \\ *e-mail: chellappa.sathyabama63@gmail.com \\ Received April 6, 2009 - Accepted May 26, 2009 - Distributed May 31, 2010 \\ (With 5 figures)
}

\begin{abstract}
The Serra Spanish mackerel, Scomberomorus brasiliensis is an important fishery resource of the Atlantic Ocean and is a major component of artisanal fisheries in northern and northeastern Brazil. Ovarian development and spawning period of $S$. brasiliensis were investigated using both macroscopic and histological techniques. Mean monthly values of GSI and ovarian maturation indicate that the main spawning period occurs during the rainy season.
\end{abstract}

Keywords: Serra Spanish mackerel, spawning period, ovarian development, histology, GSI.

\section{Desenvolvimento ovariano e desova da Serra nas águas costeiras do Nordeste do Brasil}

\section{Resumo}

A Serra, Scomberomorus brasiliensis, é uma espécie marinha de valor comercial do oceano Atlântico sendo um maior componente de pesca artesanal no norte e nordeste brasileiros. Desenvolvimento ovariano e época de desova de S. brasiliensis foram investigados utilizando-se técnicas macroscópicas e histológicas. Valores mensais médios de IGS e maturação gonadal indicam que a época de desova ocorre durante o período de chuva.

Palavras-chave: Serra, época de desova, desenvolvimento ovariano, histologia, IGS.

\section{Introduction}

The Serra Spanish mackerel, Scomberomorus brasiliensis (Collette, Russo and Zavala-Camin) (Osteichthyes: Scombridae) occurs in the Western Atlantic, along the Caribbean in Central Atlantic coasts and Southwest Atlantic from Belize to Rio Grande do Sul, Brazil (Collette et al., 1978). It is an important fishery resource of the Atlantic Ocean and is a major component of artisanal fisheries in northern and northeastern Brazil, with high commercial value. Although the importance of S. brasiliensis throughout most of its distributional range is considered vital, limited details are available regarding the gonadal development of this species. Some aspects of the reproductive biology of $S$. brasiliensis have been studied throughout its geographical range. Information on ovarian maturity required for stock assessments, is insufficiently described in the available literature which is mostly restricted to Ceará state in northeastern Brazil
(Gesteira and Ivo, 1973; Ximenes, 1981; Fonteles-Filho, 1988; Lucena et al., 2004).

Estimates of absolute and relative fecundity have been made (Gesteira, 1972; Gesteira and Mesquita, 1976; Lima et al., 2007). Studies conducted in the western coast of Maranhão, Brazil, indicate that the reproductive period of $S$. brasiliensis extends from June to November, with the participation of 3 year old females which attain sexual maturity at $411 \mathrm{~mm}$ and 4 year old males at $443 \mathrm{~mm}$ (Lima, 2004). In coastal waters of Rio Grande do Norte, females of S. brasiliensis attain gonad maturity at $280 \mathrm{~mm}$ and males at $345 \mathrm{~mm}$ of total body length (Lima et al., 2007).

However, understanding of the reproductive biology in Serra Spanish mackerel is complicated by the distribution of the population and most information has been gathered from spatially and temporally restricted 
periods. A complete description of the reproductive cycle of $S$. brasiliensis including oogenesis and spawning strategy has not been documented. Thus, a number of basic questions could be asked about the Serra Spanish mackerel population in the coastal waters of northeastern Brazil. For example, do they exhibit an annual variation in the gonadosomatic index? Do they exhibit synchronous or asynchronous spawning? Is their spawning season modulated by environmental factors?

The objective of this study was to provide a comprehensive description of the macroscopic and histological aspects of ovarian maturation of Serra Spanish mackerel, S. brasiliensis of the Atlantic Ocean coastal waters of northeastern Brazil. This study also examines the annual variation in the gonadosomatic index focusing on spawning season. Investigation was made to correlate the spawning season of this species with rainfall, one of the environmental factors known to modulate the duration and timing of the spawning period of tropical fish.

\section{Material and Methods}

\subsection{Study area and sample collection}

During the period of September 2005 to August 2006, monthly samples of Serra Spanish mackerel, $S$. brasiliensis were collected from artisanal fisheries at various locations in the coastal waters of Rio Grande do Norte, Brazil, situated between latitudes $56^{\circ} 44^{\prime}$ and $5^{\circ} 52^{\prime} \mathrm{S}$, longitudes $35^{\circ} 09^{\prime}$ and $35^{\circ} 12^{\prime} \mathrm{W}$. The samples were randomly collected from catch landed by fisherman. Fish were caught by local fishermen using beach-seines from the coastal waters of approximately $<10 \mathrm{~m}$ depth. The beach-seines were $110 \mathrm{~m}$ in length, $3 \mathrm{~m}$ in height, with a mesh size of $1 \mathrm{~cm}$ in the central part and $7 \mathrm{~cm}$ in the extremities. Fish collected from the beach-seine were numbered, measured, weighed and samples of whole fish were used for morphometric analysis to confirm the taxonomical identification of the species (Carpenter, 2002). Rainfall data of the region was obtained from the Meteorological Department of Natal, Brazil.

\subsection{Measurements}

A total of 826 fish was collected during the study period. The total body length (Lt) of fish were measured to the nearest $1 \mathrm{~mm}$ and body mass $(\mathrm{Wt})$ recorded $( \pm 1 \mathrm{~g})$. Fish were dissected within a few hours of capture, and gonads were removed, weighed $(\mathrm{Wg} \pm 0.1 \mathrm{mg}$ ) and examined to separate the sex. A total of 402 females collected were separated for detailed studies.

\subsection{Macroscopic and histological examinations of ovaries}

The location and general aspects of the ovaries were noted and stage of reproductive maturity determined using a macroscopic staging system. The ovaries were classified as Immature (small ovaries without visible oocytes), Maturing (ovaries occupying $1 / 4$ to $3 / 4$ of body cavity, with visible opaque oocytes), Mature (large ova- ries almost occupying the entire body cavity with blood capillaries), Spent (flaccid ovaries and purple in colour) (Mackie and Lewis, 2001). Turgidity, colour and presence of blood vessels of the ovaries were also observed. In order to avoid possible variation in the developmental stage of oocytes due to their position in the ovaries, histological examinations were carried out on sections from the anterior (cephalic), middle (central), and posterior (caudal) regions of 20 ovaries in different developmental stages (Yoshida, 1964).

These data were later compared in order to determine whether samples taken from mid-section of the ovary of either lobe were representative of oocyte development. The gonads were preserved in Bouin's solution, later embedded in paraffin, sectioned at 3-5 $\mu \mathrm{m}$ thickness, and stained with Harris Hematoxylin and Eosin (H\&E).

Ovarian developmental stages were assessed microscopically with the help of light microscope (Taimin, model TM 800), coupled with a video camera (Kodo Digital). The terminology used for stages of oogenesis followed that of West (1990) and Palmer et al. (1995).

\subsection{Estimation of gonadosomatic index and spawning period}

The gonadosomatic index (GSI) was calculated using the formula of Wootton et al. (1978): GSI = weight of ovary ( $\mathrm{g}$ ) / body weight of fish (g) - weight of gonads $(\mathrm{g}) \times 100$. Period of breeding was determined by the temporal relative frequency distribution of the different stages of ovarian maturation (De Martini and Fountain 1981).

\subsection{Statistical analyses}

Distributions of raw data were checked for normality and were normal log transformed when necessary. Length-weight relationships were determined using logarithmically transformed data. Pearson's correlation tests were performed to determine the correlation between the variables weight and length. Gonadosomatic indices of females during rainy and dry periods were compared at 5\% level using Mann-Whitney U test. The software package SPSS for Windows 13.0 was used for all statistical analyses.

\section{Results}

\subsection{Rainfall}

During the study period rainfall varied from a minimum of $1.2 \mathrm{~mm}$ in November, 2005 to a maximum of $427.9 \mathrm{~mm}$ in April, 2006 (138.9 \pm 135.9). Northeastern Brazil experienced 5 months of drought from September to January $(21.3 \pm 17.4)$, and 7 months of rain from February to August (206.7 \pm 128.1$)$.

\subsection{Total body length and weight}

Amplitude of total body length (Lt) of sampled females over the whole year varied from 93 to $805 \mathrm{~mm}$ $(289.2 \pm 153.4)$. During the drought period, their total 
body length ranged from 107 to 805 (312.2 \pm 176.5), and during the rainy season from 93 to $565 \mathrm{~mm}$ (275.0 \pm 135.9). A higher frequency of occurrence of females in the class intervals 100 to $200 \mathrm{~mm}$. of total body length was registered throughout the year. The amplitude of total body weight $(\mathrm{Wt})$ of the females varied from 8.1 to $3385 \mathrm{~g}$ (265.6 \pm 430.9$)$ over the year. During the drought period, total body weight of females varied from 8.1 to $4390 \mathrm{~g}(382.4 \pm 692.5)$ and during the rainy season from 11 to $1015.8 \mathrm{~g}(206.5 \pm 250.9)$. A higher frequency of occurrence of females in the class intervals 8 to $500 \mathrm{~g}$ of body weight was observed throughout the year.

The amplitude of gonad weight (Wg) varied from 0.005 to $119.99 \mathrm{~g}(2.97 \pm 0.72)$ over the year. Figure 1 shows the positive correlations between body mass and length $\left(\mathrm{r}^{2}=0.959 ; \mathrm{P}<0.0001\right)$, and between gonad weight and body mass $\left(\mathrm{r}^{2}=0.836 ; \mathrm{P}<0.0001\right)$ of females S. brasiliensis.

\subsection{Macroscopic and histological aspects of ovaries}

The ovaries were bi-lobed, elongated, and joined posteriorly to form a short gonoduct leading to the urogenital pore. The macroscopic staging of ovaries based on the external appearance showed four stages: immature, maturing, mature and spent, conforming with the litera-
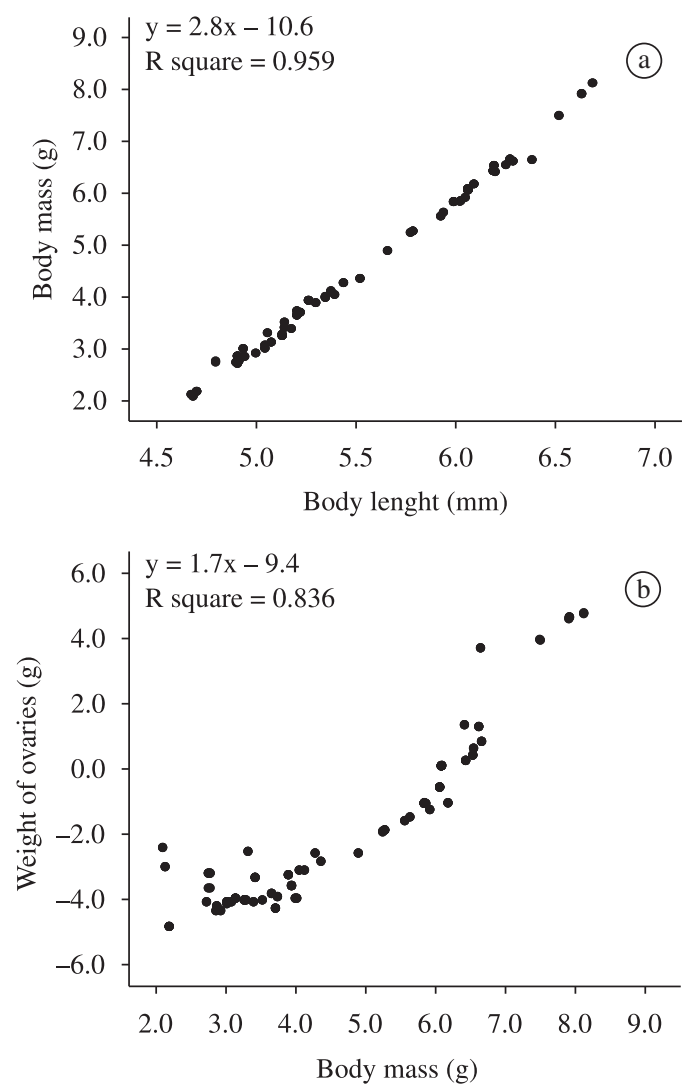

Figure 1. Correlations of (a) body mass (Wt) and length (Lt); (b) gonad weight (Wg) and body mass (Wt) of females S. brasiliensis. ture used for the methodology (Figure 2). Classification and description of the macroscopic aspects of ovarian development stages are given in Table I.

Figure 3 shows the monthly frequency of ovarian maturity stages in S. brasiliensis during the study period.

Microscopic examination of ovarian sections showed that the oocyte development was consistent along the whole length of the ovary depending on the degree of maturation. Ovaries revealed five stages of oocyte development: immature, early stage of maturing, late stage of maturing, mature and spent (Table 1, Figure 4).

\subsection{Gonado Somatic Index (GSI)}

GSI of females varied from 0.02 to $7.14(0.34 \pm$ 0.91). Monthly values of GSI of maturing, mature and spent females showed reproductive activity from March

(a)

(b)

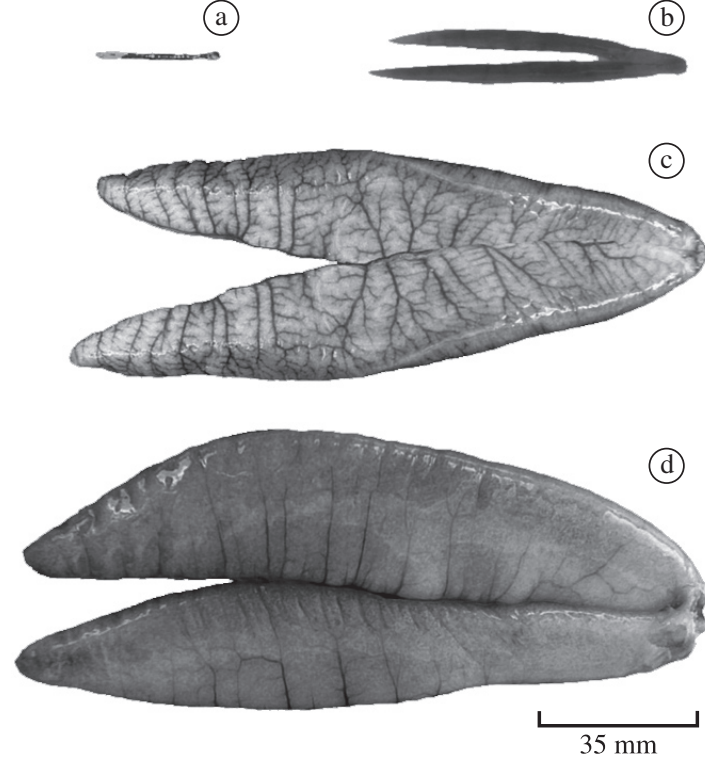

Figure 2. Macroscopic aspects of ovaries of S. brasiliensis (a) immature, (b) maturing, (c) mature and (d) spent.

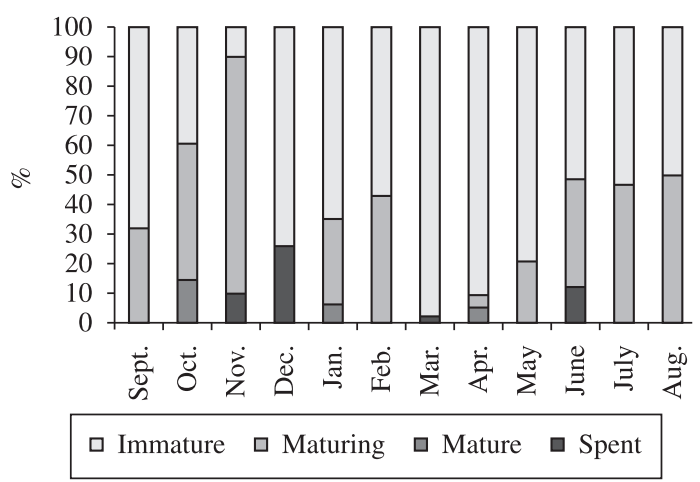

Figure 3. Monthly frequency of ovarian maturity stages in S. brasiliensis during 2005 to 2006. 
Table 1. Macroscopic and histological classification and description of the ovarian maturity stages of S. brasiliensis.

\begin{tabular}{|c|c|c|}
\hline Stage & Macroscopic description & Histological description \\
\hline Immature & $\begin{array}{l}\text { Ovaries small thread-like and } \\
\text { translucent (Figure 2a). Found } \\
\text { in fish }<200 \mathrm{~mm} \text {. }\end{array}$ & $\begin{array}{l}\text { Chromatin nucleolar stage, clusters of very small oocytes found } \\
\text { lying just beneath the ovigerous lamella; young germ cells com- } \\
\text { pactly fill the ovaries (Figure } 4 a \text { ). }\end{array}$ \\
\hline $\begin{array}{l}\text { Early stage of } \\
\text { Maturing: }\end{array}$ & $\begin{array}{l}\text { Ovaries pinkish red and trans- } \\
\text { lucent (Figure } 2 b \text { ). }\end{array}$ & $\begin{array}{l}\text { Perinucleolar stage, oocytes with nucleoli at periphery of nu- } \\
\text { cleus and cytoplasm thickens (Figure } 4 \text { b). } \\
\text { Cortical alveoli stage, oil vesicles appear (Figure } 4 c \text { ). } \\
\text { Ovaries with early yolk globule and previtellogenic stage } \\
\text { oocytes. }\end{array}$ \\
\hline $\begin{array}{l}\text { Late stage of } \\
\text { Maturing: }\end{array}$ & $\begin{array}{l}\text { Large ovaries with small } \\
\text { opaque oocytes visible to the } \\
\text { naked eye. }\end{array}$ & $\begin{array}{l}\text { Yolk stage, oocytes show the presence of yolk granules near } \\
\text { the periphery and oil vesicles within the inner region of the } \\
\text { cytoplasm (Figure } 4 \mathrm{~d} \text { ). Cytoplasmic vesicles with a uniform } \\
\text { distribution. }\end{array}$ \\
\hline Mature & $\begin{array}{l}\text { Ovaries big and turgid, red- } \\
\text { dish with numerous oocytes, } \\
\text { and intense superficial vascu- } \\
\text { larization (Figure } 2 \mathrm{c} \text { ). }\end{array}$ & $\begin{array}{l}\text { Nuclear migration and hydration stages, maturation into this } \\
\text { stage is marked by the migration of the nucleus to the periphery } \\
\text { of the oocyte, fusion of yolk granules into yolk plates and coa- } \\
\text { lescence of oil droplets. (Figure } 4 \mathrm{e} \text { ). Nucleus breaks down when } \\
\text { it reaches the periphery, hydration occurs. }\end{array}$ \\
\hline Spent & $\begin{array}{l}\text { Ovaries flaccid, pink and } \\
\text { wrinkled (Figure 2d). }\end{array}$ & $\begin{array}{l}\text { Central region of the ovaries show hemorrhaging areas, empty } \\
\text { spaces and residual oocytes in the reabsorbing process of atresia } \\
\text { (Figure } 4 \mathrm{f} \text { ). }\end{array}$ \\
\hline
\end{tabular}
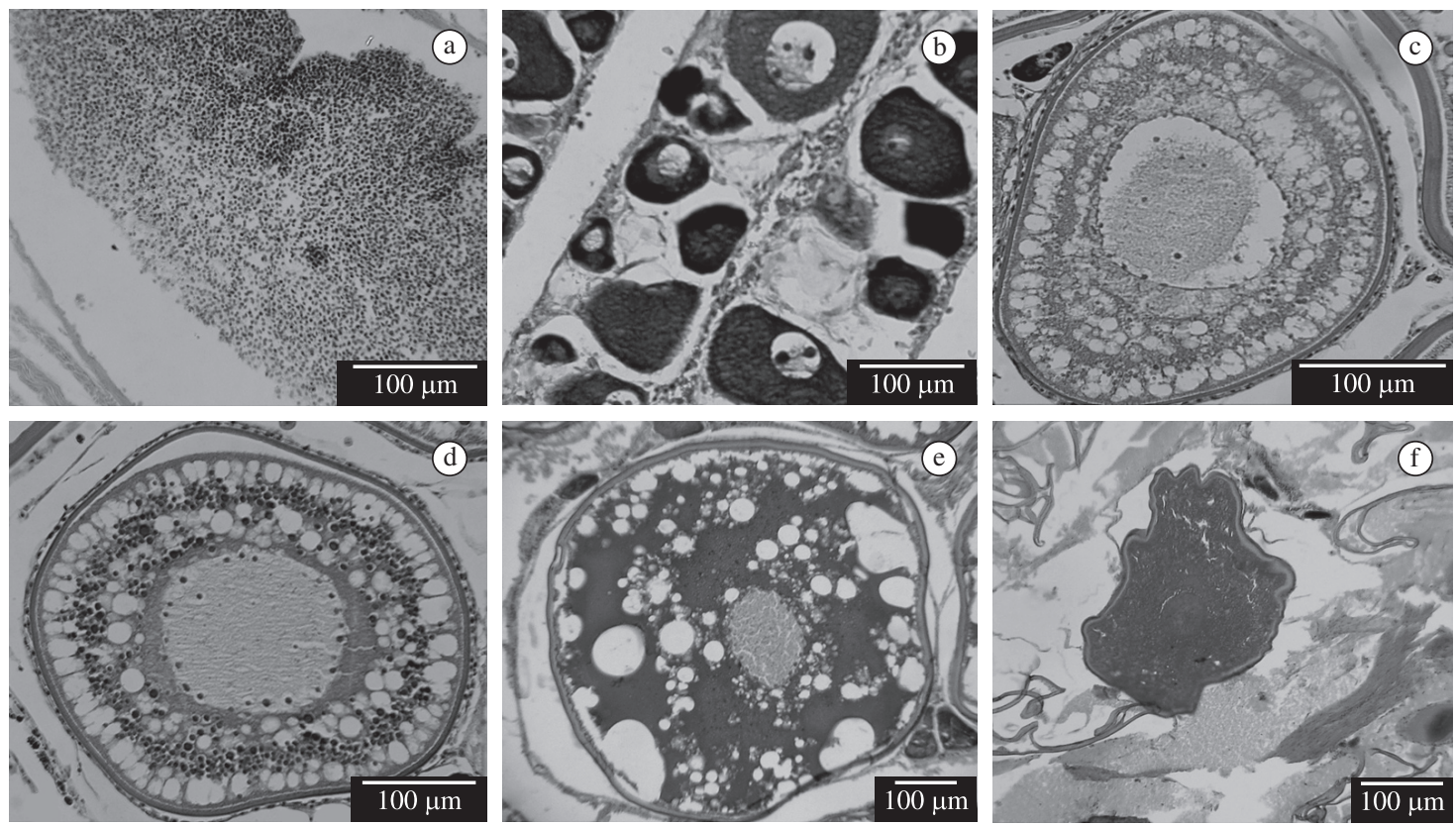

Figure 4. Histological aspects of oocyte developmental stages of S. brasiliensis: (a) nest of oogonia; (b) chromatin nucleolus stage and early perinucleolar stage oocytes; (c) oocyte in yolk vesicle stage; (d) oocyte with yolk granules and oil vesicles stage; (e) mature oocyte; (f) oocyte in the process of atresia in a spent ovary.

to June. In April adult females $(\mathrm{n}=4)$ had GSI varying from 0.14 to $3.24(1.69 \pm 1.78)$ and in June $(n=16)$ from 0.08 to $4.14(1.10 \pm 1.81)$ (Figure 5). Reproductive activity occurred during the rainy season which lasted from February to August. During the rainy period, GSI of females varied from 0.02 to $4.14(0.27 \pm 0.67)$ and during the dry season, GSI ranged from 0.02 to 7.14 $(0.46 \pm 1.19)$. The highest GSI (7.14) of females in November was due to one mature individual. The differences in the mean values of GSI in drought and rainy periods showed significant difference $(\mathrm{P}<0.001)$ (Figure 5). 


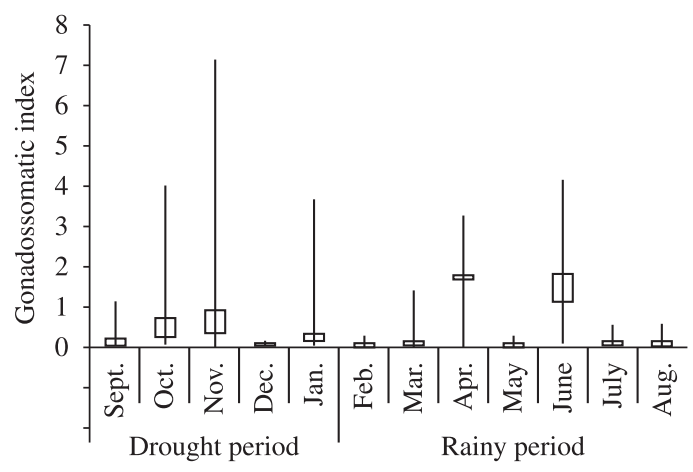

Figure 5. Monthly variation in Gonadossomatic Index (GSI) of S. brasiliensis during 2005 to 2006.

\subsection{Spawning period}

Large mature females had on an average a total body length of $712.7 \mathrm{~mm}( \pm 117.3)$ and weight of $2476.9 \mathrm{~g}$ $( \pm 1043.82)$, with ovaries on an average weighing $71.3 \mathrm{~g}$ $( \pm 36.8)$. Mature ovaries showed the reserve stock of perinucleolar stage oocytes (phase II) with diameter size $<120 \mu \mathrm{m}$ and mature oocytes with diameters ranging from 600 to $750 \mu \mathrm{m}$. Evidence of spawning was found in the histologically processed ovaries. The peak reproductive activity occurred during March to June, coinciding with the rainy season which lasted from February to August.

\section{Discussion}

The present study documents the changes in the ovarian activity and spawning in Serra Spanish mackerel occurring in the coastal waters of Rio Grande do Norte in northeastern Brazil. Growth of females in weight reflects the reproductive cycle, as the ovaries mature they increase in weight which adds to the total weight of fish. Differences in growth patterns of females can thus provide a mechanism for an adaptive phenotypic response to changes in tropical coastal environments.

The onset of sexual maturity represents a critical transition in the life history, since resource allocation is related mainly to growth before and to reproduction after sexual maturity (Potts and Wootton, 1984; Chellappa et al., 1995). The present study establishes four macroscopic stages and five stages of ovarian oocyte development for females of Serra Spanish mackerel. The macroscopic classification and histological analyses of the ovaries suggest that there is a regular pattern of gonadal development for each maturity stage, such as the immature, developing, mature and spent stages. An earlier study has revealed the ovarian developmental stages for the narrow-barred Spanish mackerel, Scomberomorus commerson, in Western Australia (Mackie and Lewis, 2001) and a similar pattern was observed in the present study.

The reproductive process, such as gonad maturation, in tropical fishes is influenced by various environmental changes induced by the onset of rains. Drought is a natural climatic situation which is characteristic of northeastern Brazil, with an irregular pattern of distribution of rain in the region. The spawning characteristics of females of Serra Spanish mackerel showed that the peak period of reproductive activity was during March-June coinciding with the rainy season and very few spawning fish were found outside these months. The macroscopic and histological analysis of ovaries equally confirmed that breeding season commenced with the onset of rains.

In tropical regions the rainfall plays an important role in determining the reproductive cycles of fishes and collective reproduction occurs during the time when environmental conditions are favourable for the survival of juvenile forms and when adequate food is available, besides protection from predators. Monthly variations of GSI of Serra Spanish mackerel showed that peak breeding coincides with rainy season and possibly better environmental conditions.

It is interesting to observe that the peak breeding season of Serra Spanish mackerel in northeastern Brazil takes place in a sequential manner. In the coastal areas of Natal the spawning season is from March-June whereas in the Maranhão coastal waters of Brazil spawning occurs in October (Batista and Fabré, 2001), and from June to November (Lima, 2004). A similar trend was observed in Australia for Spanish mackerel S. commerson Lacepède (Mackie et al., 2005). These probably reflect their migratory route for feeding and reproductive purposes.

Conservation of fish stocks in their natural habitat are usually endangered by abusive fishing of immature fishes which have not yet completed their reproductive cycle, as recruitment via reproduction is the means by which the resource is renewed. The REVIZEE SCORE-NE Program has carried out various extensive surveys to determine the conservation status of the of the fish stocks in their natural habitats. This report emphasises the importance of Serra S. brasiliensis as an important fishery resource in northeastern Brazil, based on the surveys carried out in the northeastern continental shelf waters (Lessa, 2006). These reports indicate that the annual rate of exploration of the Serra stock is around $25 \%$ to $29 \%$ in the northeastern coastal region, which is close to its maximum sustainable exploratory limit. This stock shows a declining tendency of its population (Nóbrega, 2002).

The traditional fishing communities depend on small scale artisanal fishery, which reflects their way of making a living and sustains their lifestyle. Though it is important to preserve this traditional fishery, it is also vital to programme the sustainability and conservation of coastal fisheries resources. The predatory fishing technique of beach seine nets, in which small mesh sizes are used in order to catch marine shrimps, accounts for a large bycatch of small sized immature Serra Spanish mackerel. The artisanal fishery beach-seines are operated in the shallow coastal waters, which captures the immature individuals of the pelagic stock. Measures should be taken 
to regulate this fishery in order to conserve this valuable fishery resource by increasing the size of capture.

Acknowledgements - The authors wish to thank the National Council for Scientific and Technological Development of Brazil $(\mathrm{CNPq})$ for the financial support awarded during the study period (J. T. A. Ximenes de Lima, Grant $n^{\circ}$. 141651/2005-9) and for the Research grants awarded (S. Chellappa, Grant $\mathrm{n}^{\circ}$. 307497/2006-2, A. Araújo, Grant n ${ }^{\circ} .302012 / 2006-0$ and N. T. Chellappa, Grant $n^{\circ}$. 306274/2003-5). The authors thank the REVIZEE SCORE-NE Program for the valuable data made available to the public through the extensive fishery resource surveys carried out in the northeastern continental shelf waters.

\section{References}

BATISTA, VS. and FABRÉ, NN., 2001. Temporal and spatial patterns on Serra, Scomberomorus brasiliensis (Teleostei, Scombridae) catches from the fisheries on the Maranhão coast. Brazil. Revista Brasileira de Biologia = Brazilian Journal of Biology, vol. 61, no. 4, p. 541-546.

CARPENTER, KE., 2002. The living marine resources of the Western Central Atlantic. Roma: FAO Species Identification Guide for Fishery Purposes; American Society of Ichthyologists and Herpetologists. p. 1-184. (vol. 2, Bony fishes, special publication no. 5)

CHELLAPPA, S., HUNTINGFORD, FA., STRANG, RHC. and THOMSON, RY., 1995. Condition factor and hepatosomatic index as estimates of energy status in male three-spined stickleback. Journal of Fish Biology, vol. 47, no. 5, p. 775-787.

COLLETTE, BB., RUSSO, JL. and ZAVALA-CAMIN, LA., 1978. Scomberomorus brasiliensis, a new species of Spanish mackerel from the western Atlantic. Fishery Bulletin, vol. 76, no. 1, p. 273-280.

FONTELES-FILHO, AA., 1988. Sinopse de informações sobre a biologia e pesca da cavala, Scomberomorus cavalla e da serra Scomberomorus brasiliensis, no Estado do Ceará (Brasil). Arquivos de Ciências do Mar, vol. 27, no. 2, p. 13-31.

GESTEIRA, TC., 1972. Sobre a reprodução e fecundidade da serra, Scomberomorus maculatus (Mitchill), no Estado do Ceará. Arquivos de Ciências do Mar, vol. 12, no. 2, p. 117-122.

GESTEIRA, TC. and IVO, CTC., 1973. Estudo da reprodução, tamanho e idade de primeira desova da cavala e da serra na costa do Estado do Ceará (Brasil). Arquivos de Ciências do Mar, vol. 16 , no. 2, p. 83-88.

GESTEIRA, TC. and MESQUITA, ALL., 1976. Época de reprodução, tamanho e idade na primeira desova da cavala e da serra, na costa do Estado do Ceará (Brasil). Arquivos de Ciências do Mar, vol. 16, no. 2, p. 83-86.

LESSA, RP., 2006. Recursos pesqueiros da região nordeste. In Ministério do Meio Ambiente - MMA. Avaliação do potencial sustentável de recursos vivos na zona econômica exclusiva. Brasília: MMA. p. 153-180. (Programa REVIZEE, Relatório Executivo).
LIMA, PRS., 2004. Dinâmica populacional da Serra Scomberomorus brasiliensis (Osteichthyes; Scombridae), no litoral ocidental do Maranhão-Brasil. Recife: Universidade Federal Rural de Pernambuco. 45 p. [Dissertação de Mestrado].

LIMA, JTAX., FONTELES-FILHO, AA. and CHELLAPPA, S., 2007. Biologia reprodutiva da Serra, Scomberomorus brasiliensis (Osteichthyes: Scombridae), em águas costeiras do Rio Grande do Norte. Arquivos de Ciências do Mar, vol. 40, no. 1, p. 24-30.

LUCENA, F., LESSA, RP., KOBAYASHI, R. and QUIORATO, A., 2004.Aspectos biológico-pesqueiros daserra Scomberomorus brasiliensis capturada com rede de espera no nordeste do Brasil. Arquivos de Ciências do Mar, vol. 37, no. 1, p. 93-104.

MACKIE, MC. and LEWIS, PD., 2001. Assessment of gonad staging systems and other methods used in the study of the reproductive biology of the narrow-barred Spanish mackerel, Scomberomorus commerson, in Western Australia. Fisheries Research Report, vol. 99, no. 136, 48 p.

MACKIE, MC., LEWIS, PD., GAUGHAN, DJ. and NEWMAN, SJ., 2005. Variability in spawning frequency and reproductive development of the narrow-barred Spanish mackerel (Scomberomorus commerson) along the west coast of Australia. Fishery Bulletin, vol. 103, no. 2 , p. 344-354.

MARTINI, EE. and FOUNTAIN, R., 1981. Ovarian cycling frequency and batch fecundity in the queenfish, Seriphus politus: attributes representative of serial spawning fishes. Fishery Bulletin, vol. 79, no. 3, p. 547-559.

NOBREGA, MF. 2002. Idade, crescimento e avaliação de estoque da serra, Scomberomorus brasiliensis (Teleostei: Scombridae) na Plataforma Continental do Nordeste do Brasil. Recife: Universidade Federal Rural de Pernambuco. 106 p. [Dissertação de Mestrado].

PALMER, EE., SORENSEN, PW. and ADELMAN, IR., 1995. A histological study of seasonal ovarian development in freshwater drum in the Red Lakes, Minnesota. Journal of Fish Biology, vol. 47, no. 2, p. 199-210.

POTTS, GW. and WOOTTON, RJ., 1984. Fish reproduction: strategies and tactics. London: Academic Press. 410 p.

WEST, G., 1990. Methods of assessing ovarian development in Fishes: a review. Australian Journal of Marine and Freshwater Research, vol. 41, no. 2, p. 199-222.

WOOTTON, RJ., EVANS, GW. and MILLS, LA., 1978. Annual cycle in female three-spined sticklebacks (Gasterosteus aculeatus L.) from an upland and lowland population. Journal of Fish Biology, vol. 12, no. 4, p. 331-343.

XIMENES, MOC., 1981. O crescimento da serra, Scomberomorus brasiliensis do estado do Ceará. Arquivos de Ciências do Mar, vol. 21, no. 1-2, p. 47-54.

YOSHIDA, HO., 1964. Skipjack tuna spawning in the Marquesas Islands and Tuamotu Archipelago. Fishery Bulletin, vol. 65 , no. 2 , p. $479-488$. 